\title{
Dependence of Quantitative and Qualitative Parameters of Radish Yield on Contents of Ammonium and Nitrate Nitrogen in Soil Substrate
}

\author{
Peter Kováčik', Barbara Wiśniowska-Kielian²*, Sylwester Smoleń3, \\ Petr Škarpa ${ }^{4}$, Katarína Olšovská5 ${ }^{\text {, Jana Urminská6 }}$
}

1 Slovak University of Agriculture in Nitra, Department of Agrochemistry and Plant Nutrition, Tr. A Hlinku 2, 94901 Nitra, Slovakia

2 University of Agriculture in Kraków, Department of Agricultural and Environmental Chemistry, 21 A. Mickiewicza Ave., 31-120 Kraków, Poland

3 University of Agriculture in Kraków, Institute of Plant Biology and Biotechnology, Al. 29 Listopada 54, 31425 Kraków, Poland

${ }^{4}$ Mendel University in Brno, Department of Agrochemistry, Soil Science, Microbiology and Plant Nutrition, Zemědělská 1, Brno, CZ-613 00, Czech Republic

5 Slovak University of Agriculture in Nitra, Department of Plant Physiology, Tr. A Hlinku 2, 94901 Nitra, Slovakia

${ }^{6}$ Slovak University of Agriculture in Nitra, Department of Chemistry, Tr. A Hlinku 2, 94901 Nitra, Slovakia

* Corresponding author's e-mail: rrkielia@cyf-kr.edu.pl

\begin{abstract}
Plant nutrition is one of the significant factors determining the quantity and quality of crop production. Therefore, the objective of the experiment was to express the dependence numerically (statistically) of the selected yield parameters of radish on the contents of ammonium and nitrate nitrogen occurring in the soil growing medium in different periods of radish vegetation. The experiment was performed in the plastic greenhouse with aeration and irrigation manually operated. It had three variants and was established by the method of random plot arrangement with a threefold repetition of variants. The variants differed in the quantity of vermicompost in the soil growing medium $(0 \%, 10 \%, 20 \%)$. The achieved results indicate that the yield parameters of radish were more dependent on the contents of $\mathrm{N}^{-} \mathrm{NO}_{3}^{-}$than on the contents of $\mathrm{N}-\mathrm{NH}_{4}^{+}$occurring in the soil substrate. The quantity of $\mathrm{N}-\mathrm{NO}_{3}^{-}$, occurring in the soil growing medium in the initial period of the growing season, had impact on the quantity of yield. The quantity of $\mathrm{N}^{-\mathrm{NO}_{3}}$, present in the soil substrate in the second half of the growing season, had impact mainly on the content of vitamin $\mathrm{C}$ and content of nitrates in roots. As the $\mathrm{N}-\mathrm{NO}_{3}$ - content of the soil growing medium increased, the content of nitrates was increased and content of vitamin $\mathrm{C}$ was decreased. The dependence between the contents of $\mathrm{N}_{-} \mathrm{NH}_{4}^{+}$in the substrate and root yield was insignificant. The quantity of radish root yield depended predominantly on the contents of $\mathrm{N}_{\mathrm{in}}$ occurring in the soil growing medium at the beginning of the growing season. On the contrary, the content of nitrates and vitamin $\mathrm{C}$ (influencing the yield quality) was dependent mostly on the contents of $\mathrm{N}_{\text {in }}$ present in the soil substrate in the second half of radish growing season. Along with the increase in the content of $\mathrm{N}_{\text {in }}$, the root yield and the content of nitrates in roots also increased, while the content of vitamin $\mathrm{C}$ was decreased.
\end{abstract}

Keywords: radish, vitamin C, nitrates, nitrogen, soil, dependence

\section{INTRODUCTION}

Nitrogen has the significant impact on the yield parameters of the cultivated crops. Its influence on the yield quantity is the most important out of all nutrients (macroelements and microelements). As a result, even in periods of unfavourable economic conditions, the farmers are always able to obtain income for the purchase and application of nitrogen fertilizers (Kováčik \& Ryant, 2019). 
Nitrogen plays a key role in the global food security (Mueller et al., 2012). Therefore, many agricultural researchers concentrate special attention on nitrogen fertilization. They are searching for the optimal doses and dates of application of the whole spectrum of $\mathrm{N}$ fertilizers - inorganic, organic, fast or slow releasing (Fageria \& Baligar, 2005, Kováčik et al., 2016, Jin et al., 2019, Liu et al., 2019). A balance is sought between nitrogen input to the soil and plants' requirements for this component, while maintaining soil fertility and avoiding deterioration of the quality of environment with the target of the crop cultivation with high nutritional value by the economically effective way (Lassaletta et al., 2014, Zhang et al., 2015, Prasad \& Shivay, 2016, Rodrigues et al., 2019). The objective to cultivate crops at a high quality level is apparent from the fact that the human nutrition participates by $80 \%$ in the health condition of population, and $74 \%$ of people's deaths is related directly or indirectly to their nutrition (Zachar, 2006).

The implementation of the latest scientific knowledge into the agricultural production constitutes the yield increase and consequently the growth of competition between growers. In order to bring their products to the European market where the food supply is big, the farmers have to pay a greater attention to the quality of cultivated crops year-overyear. The quality has and will have still more important role in selling and purchase of the agricultural commodities. Taking into account this fact, an experiment was established in the area of the Slovak University of Agriculture in Nitra. The objective of the experiment was to acquire information about the statistical dependence of yield quantity and quality of the model crop on the contents of ammonium and nitrate nitrogen in the soil, determined in the different growth periods of radish.

\section{MATERIALS AND METHODS}

\section{Experimental design and field management}

The stated issue was studied in the course of three years (2014 to 2016) in the small-plot experiment located in the area of the Slovak University of Agriculture in Nitra $\left(48^{\circ} 18^{\prime} \mathrm{N}\right.$, $18^{\circ} 06^{\prime} \mathrm{E}$ - Slovakia) in the plastic greenhouse with the mechanic aeration and irrigation, on the substrate consisting of soil (S) and vermicompost $(\mathrm{Vc})$. The substrate was being prepared every year. The agrochemical soil parameters (Haplic Luvisol) and vermicompost, used for the preparation of substrate, are indicated in the Table 1.

The experiment had three variants $(a, b, c)$ and was established by the method of random plot arrangement with threefold repetition of variants. Variant a - control variant (soil, Haplic Luvisol-HL). Variant $b-$ the substrate consisting of 9 portions of soil (HL) and 1 portion of vermicompost $(9: 1, \mathrm{v} / \mathrm{v}, 10 \% \mathrm{Vc})$. Variant $\mathrm{c}-$ the substrate consisting of soil (HL) and vermicompost mixed in the ratio $4: 1(4: 1, \mathrm{v} / \mathrm{v}, 20 \% \mathrm{Vc})$. The prepared substrates were brought in the plastic greenhouse three months before sowing the model crop and layered on the soil (HL) to a height of $24 \mathrm{~cm}$ and subsequently rolled.

The model crop, radish (Raphanus sativus var. radicula Pers.), variety Granát delivered by the company Osiva Moravia, was sown manually to the precise number of individuals. The row spacing was $15 \mathrm{~cm}$ and the distance in the row was $2 \mathrm{~cm}$. The dimensions of one plot were $1.7 \times 1.2 \mathrm{~m}$. The sowing was repeated in the first March week every year. After sowing the substrate humidity was retained at the level $65-70 \%$ FWC (full water capacity) with the regular watering by tap drinking water (left to stand), containing negligible quantity of nutrients. Every year the soil samples were collected on 22nd, 32nd, 42nd and 52nd day after radish sowing (in the growth phases - the third proper leaf, the beginning of formation of the fifth proper leaf, the sixth proper leaf, the beginning of formation of the seventh proper leaf). The soil samples were taken from each variant and repetition, in particular from two soil layers $(0.0-0.1 \mathrm{~m}$ and 0.1-0.2 m). In the fresh soil samples the content of ammonium $\left(\mathrm{N}-\mathrm{NH}_{4}^{+}\right)$and nitrate $\left(\mathrm{N}-\mathrm{NO}_{3}^{-}\right)$ nitrogen was determined. On the 52nd day after

Table 1. Agrochemical parameters of soil and vermicompost used for the production of substrates

\begin{tabular}{|c|c|c|c|c|c|c|c|c|c|c|c|}
\hline \multirow{2}{*}{ Substrate } & $\mathrm{N}-\mathrm{NH}_{4}^{+}$ & $\mathrm{N}-\mathrm{NO}_{3}^{-}$ & $\mathrm{N}_{\text {in }}$ & $\mathrm{P}$ & $\mathrm{K}$ & $\mathrm{Ca}$ & $\mathrm{Mg}$ & $S$ & $\mathrm{~N}_{\mathrm{t}}$ & \multirow{2}{*}{$\frac{\mathrm{C}_{\mathrm{ox}}}{\left(\mathrm{g} \cdot \mathrm{kg}^{-1}\right)}$} & \multirow{2}{*}{$\mathrm{pH}_{\mathrm{KC}}$} \\
\hline & \multicolumn{9}{|c|}{$\left(\mathrm{mg} \cdot \mathrm{kg}^{-1}\right)$} & & \\
\hline$S$ & 4.8 & 7.8 & 12.6 & 19.8 & 190 & 2,100 & 460 & 7.5 & 748 & 8.82 & 6.20 \\
\hline Vc & 94.8 & 171.7 & 266.5 & 4,150 & 18,625 & 6,500 & 3,435 & 1,938 & 13,540 & 206.1 & 7.31 \\
\hline
\end{tabular}

$\mathrm{S}$ - soil, Vc - vermicompost 
sowing the root yield was evaluated. Only those roots were evaluated which the average width (root diameter) was $\geq 1.5 \mathrm{~cm}$. The content of vitamin $\mathrm{C}$ and nitrates was determined in the roots.

\section{Chemical analysis}

For the determination of selected parameters of soil, vermicompost and substrate the analytical methods commonly used in chemical-agricultural research were applied. $\mathrm{N}-\mathrm{NH}_{4}^{+}$was determined by Nessler's colorimetric method; $\mathrm{N}-$ $\mathrm{NO}_{3}^{-}$by colorimetric method with phenol-2.4disulphonic acid, after extraction of these $\mathrm{N}$-forms from the soil by using the $1 \% \mathrm{~K}_{2} \mathrm{SO}_{4}$ water solution. $\mathrm{N}_{\text {in }}$ was calculated as a sum of $\mathrm{N}-\mathrm{NH}_{4}^{+}+\mathrm{N}^{-\mathrm{NO}_{3}}{ }^{-}\left(\mathrm{N}_{\text {in }}=\mathrm{N}-\mathrm{NH}_{4}^{+}+\mathrm{N}-\mathrm{NO}_{3}^{-}\right)$. The contents of available $\mathrm{P}, \mathrm{K}, \mathrm{Ca}$ and $\mathrm{Mg}$ were determined by Mehlich 3 extraction procedure (Mehlich, 1984). The content of P was determined by colorimetric method after formation of phosphomolybdate complex, $\mathrm{K}$ by flame photometry, $\mathrm{Ca}$ and $\mathrm{Mg}$ by atomic absorption spectrophotometry, S spectrophotometrically (in the leachate of ammonium acetate), $\mathrm{N}_{\mathrm{t}}$ by distillation after the mineralization of strong $\mathrm{H}_{2} \mathrm{SO}_{4}$ (by the Kjeldahl method - Bremner, 1960), $\mathrm{C}_{\text {ox }}$ spectrophotometrically after the oxidation according to Tiurin (Dziadowiec \& Gonet, 1999) and $\mathrm{pH}_{\mathrm{KCl}}$ potentiometrically in solution of $1.0 \mathrm{~mol} \cdot \mathrm{dm}^{-3}$ $\mathrm{KCl}(1: 2.5$, soil:solution ratio).

The two radish quality parameters content of vitamin $\mathrm{C}$ and of nitrates were determined. The content of vitamin $\mathrm{C}$ was determined by titric method using 2,6-dichlorophenolindophenol (Ball, 1998). In order to determine nitrates (expressed as $\mathrm{NaNO}_{3}$ ), ion-selective electrode of the type 07-35 and reference electrode of the type RCE 101 were used (Hubáček \& Bernatzik, 1979).

\section{Statistical analysis}

The acquired results were processed by correlation analysis at the significance levels $\alpha=$ 0.05 and $\alpha=0.01$. Pearson correlation coefficients (r) were calculated. Some results were processed by analysis of variance (ANOVA). The differences between the treatments were evaluated by LSD test at the significance level $\alpha=0.05$. The PC statistical program "Statgraphics, version 5.0" was used.

\section{RESULTS AND DISCUSSION}

The objective of the experiment was to express statistically the dependence of quantity and quality of radish yield on the contents of ammonium and nitrate nitrogen in soil in the different periods of radish vegetation. Therefore, in the paper only results of statistical analyse of effect of the applied fertilisation on the values of radish root yield parameters in individual years of the experiment are presented (Table 2), and there is not statistically or in the written form evaluated the impact of the experiment variants on the temporal dynamics of contents of inorganic nitrogen forms in the substrate. However, the measured values of these parameters are given in the Tables 3 and 4 because, based on them, the correlation dependences of the quantitative and qualitative parameters of radish yield on the content of inorganic nitrogen in the soil substrate were assessed.

The data in the Table 5 confirm the significant correlation dependence of the yield parameters of radish roots on the contents of inorganic nitrogen detected in both layers of the soil substrate during the whole monitored period. The positive correlation dependence was recorded between the weight of roots (yield) and the contents $\mathrm{N}_{\text {in }}$ in substrates and also between the nitrates content in roots and $\mathrm{N}_{\text {in }}$ in substrates. On the contrary, the negative dependences were detected between the contents $\mathrm{N}_{\text {in }}$ and vitamin $\mathrm{C}$. These facts affirm that along with the growth of $\mathrm{N}_{\text {in }}$ content in the soil substrate, the yield quantity was rising and quality deteriorated (the nitrates content was increased and content of vitamin $\mathrm{C}$ was decreased). These data were valid for both substrate layers. The correlation coefficient (r), expressing the dependence of the quantity of root yield on the contents $\mathrm{N}_{\text {in }}$ registered in the upper layer of the substrate was higher, in comparison with the coefficient valid for the lower layer of the substrate. On the contrary, correlation coefficients (r), expressing the dependence of nitrates content and vitamin $\mathrm{C}$ on $\mathrm{N}_{\text {in }}$ contents located in the upper layer of the soil substrate was lower compared with the coefficients valid for the lower layer of the substrate. This is the evidence that nitrogen taken by plants from the upper layers (at the beginning of growth season) determines predominantly the yield quantity and nitrogen taken from the lower layers (in later period) determines mostly yield quality. The similar finding, i.e. that the quantity of yield of spring barley grains is influenced 
Table 2. Radish root yield parameters (average values) in individual years of the experiment

\begin{tabular}{|c|c|c|c|c|c|c|c|c|c|}
\hline \multirow{3}{*}{ Variant } & \multicolumn{3}{|c|}{ Root (weight) yield } & \multicolumn{3}{|c|}{$\mathrm{NaNO}_{3}$} & \multicolumn{3}{|c|}{ Vitamin C } \\
\hline & \multicolumn{3}{|c|}{$\left(g \cdot m^{-2}\right)$} & \multicolumn{6}{|c|}{$\left(\mathrm{mg} \cdot \mathrm{kg}^{-1}\right)$} \\
\hline & 2014 & 2015 & 2016 & 2014 & 2015 & 2016 & 2014 & 2015 & 2016 \\
\hline$S$ & $1,807^{b}$ & $1,367^{a}$ & $1,933^{a}$ & $2,150^{a}$ & $2,620^{a}$ & $2,606^{a}$ & $382^{c}$ & $330^{c}$ & $340^{c}$ \\
\hline$S+V c(9: 1)$ & $2,084^{c}$ & $1,820^{b}$ & $2,290^{b}$ & $2,550^{b}$ & $2,700^{\mathrm{b}}$ & $2,780^{b}$ & $348^{b}$ & $300^{b}$ & $326^{b}$ \\
\hline$S+V c(4: 1)$ & $1,660^{\mathrm{a}}$ & $2,033^{c}$ & $2,433^{c}$ & $2,660^{c}$ & $2,700^{b}$ & $2,995^{c}$ & $338^{a}$ & $290^{a}$ & $290^{a}$ \\
\hline
\end{tabular}

$\mathrm{S}$ - soil, Vc - vermicompost

Values with different letters in superscript differ significantly at $\mathrm{P}<0.05$

Table 3. Dynamics of changes of inorganic nitrogen contents in the soil substrates in the layer $0.0-0.1 \mathrm{~m}$ during radish growing season

\begin{tabular}{|c|c|c|c|c|c|c|}
\hline \multirow{3}{*}{ Form of $\mathrm{N}$} & \multirow{3}{*}{ Year } & \multirow{3}{*}{ Variant } & \multicolumn{4}{|c|}{ Number of days after sowing } \\
\hline & & & 22 & 32 & 42 & 52 \\
\hline & & & \multicolumn{4}{|c|}{$\left(\mathrm{mg} \cdot \mathrm{kg}^{-1}\right)$} \\
\hline \multirow{9}{*}{$\mathrm{N}-\mathrm{NO}_{3}^{-}$} & \multirow{3}{*}{2014} & a & 80.00 & 56.25 & 16.00 & 10.00 \\
\hline & & $\mathrm{b}$ & 158.00 & 151.25 & 93.28 & 60.13 \\
\hline & & c & 71.63 & 100.00 & 64.00 & 62.05 \\
\hline & \multirow{3}{*}{2015} & a & 75.50 & 51.00 & 26.00 & 28.60 \\
\hline & & $b$ & 111.00 & 105.00 & 90.05 & 75.75 \\
\hline & & c & 132.00 & 120.00 & 88.45 & 70.60 \\
\hline & \multirow{3}{*}{2016} & a & 60.00 & 40.00 & 25.75 & 19.00 \\
\hline & & $\mathrm{b}$ & 205.00 & 197.50 & 100.00 & 66.00 \\
\hline & & $\mathrm{c}$ & 211.25 & 180.00 & 105.00 & 103.50 \\
\hline \multirow{9}{*}{$\mathrm{N}-\mathrm{NH}_{4}^{+}$} & \multirow{3}{*}{2014} & a & 9.20 & 8.38 & 20.00 & 24.20 \\
\hline & & $\mathrm{b}$ & 11.13 & 10.63 & 27.00 & 26.95 \\
\hline & & c & 16.00 & 12.33 & 26.25 & 33.80 \\
\hline & \multirow{3}{*}{2015} & $a$ & 11.90 & 13.00 & 20.00 & 25.40 \\
\hline & & $\mathrm{b}$ & 14.50 & 16.50 & 29.00 & 34.40 \\
\hline & & $c$ & 16.90 & 19.90 & 29.00 & 36.60 \\
\hline & \multirow{3}{*}{2016} & $a$ & 6.50 & 3.75 & 20,00 & 23.00 \\
\hline & & $\mathrm{b}$ & 7.75 & 4.75 & 25,00 & 30.00 \\
\hline & & c & 6.50 & 4.75 & 23.50 & 34.00 \\
\hline \multirow{9}{*}{$\mathrm{N}_{\text {in }}$} & \multirow{3}{*}{2014} & $a$ & 89.2 & 64.63 & 36.0 & 34.20 \\
\hline & & $b$ & 169.13 & 161.88 & 120.28 & 87.08 \\
\hline & & $c$ & 87.63 & 112.33 & 90.25 & 95.85 \\
\hline & \multirow{3}{*}{2015} & $a$ & 87.40 & 64.00 & 46.00 & 54.00 \\
\hline & & $b$ & 125.50 & 121.50 & 119.05 & 110.15 \\
\hline & & c & 148.90 & 139.90 & 117.45 & 107.20 \\
\hline & \multirow{3}{*}{2016} & $a$ & 66.50 & 43.75 & 45.75 & 42.00 \\
\hline & & $\mathrm{b}$ & 212.75 & 202.25 & 125.00 & 96.00 \\
\hline & & c & 217.75 & 184.75 & 128.50 & 137.50 \\
\hline
\end{tabular}

predominantly by nitrogen uptake within the first 45days of the growing season (nitrogen absorbed from tillable, or humus soil layer), and the quality of grain yield (content of $\mathrm{N}$ substances) is influenced by nitrogen absorbed from the soil layer from 0.3 to $0.6 \mathrm{~m}$ - has already been presented by Kováčik (2009).

The recorded dependence of the radish yield parameters on the contents $\mathrm{N}_{\text {in }}$ corresponds with the attainments of Šlosár et al.
(2009) who recorded the negative impact of $\mathrm{N}$ fertilizers on the broccoli quality (increased nitrate content). Similarly, Uher et al. (2017) recorded the increased content of nitrates in cauliflower (quality deterioration) after the application of nitrogen fertilizers into soil. Vice versa, in the carrot cultivation, Smolen and Sady (2009a) in some cases recorded after the application of $\mathrm{N}$ fertilizers the improvement of some qualitative parameters (concentration 
Table 4. Dynamics of changes of inorganic nitrogen contents in the soil substrates in the layer $0.1-0.2 \mathrm{~m}$ during radish growing season

\begin{tabular}{|c|c|c|c|c|c|c|}
\hline \multirow{3}{*}{ Forma N } & \multirow{3}{*}{ Year } & \multirow{3}{*}{ Variant } & \multicolumn{4}{|c|}{ Number of days after sowing } \\
\hline & & & 22 & 32 & 42 & 52 \\
\hline & & & \multicolumn{4}{|c|}{$\left(\mathrm{mg} \cdot \mathrm{kg}^{-1}\right)$} \\
\hline \multirow{9}{*}{$\mathrm{N}-\mathrm{NO}_{3}^{-}$} & \multirow{3}{*}{2014} & a & 47.25 & 40.20 & 18.40 & 6.60 \\
\hline & & $\mathrm{b}$ & 122.15 & 102.25 & 70.20 & 40.60 \\
\hline & & c & 84.70 & 80.60 & 64.00 & 58.40 \\
\hline & \multirow{3}{*}{2015} & a & 33.50 & 30.20 & 30.10 & 30.00 \\
\hline & & $\mathrm{b}$ & 94.30 & 90.40 & 77.20 & 50.50 \\
\hline & & $\mathrm{c}$ & 100.00 & 96.60 & 79.10 & 55.50 \\
\hline & \multirow{3}{*}{2016} & a & 41.00 & 39.50 & 19.10 & 17.50 \\
\hline & & $\mathrm{b}$ & 128.60 & 117.50 & 61.75 & 40.50 \\
\hline & & c & 150.00 & 120.20 & 98.40 & 68.60 \\
\hline \multirow{9}{*}{$\mathrm{N}-\mathrm{NH}_{4}^{+}$} & \multirow{3}{*}{2014} & a & 9.98 & 8.25 & 10.00 & 11.75 \\
\hline & & $\mathrm{b}$ & 10.50 & 12.00 & 11.50 & 11.50 \\
\hline & & $\mathrm{c}$ & 10.75 & 9.25 & 14.00 & 14.00 \\
\hline & \multirow{3}{*}{2015} & $a$ & 12.20 & 14.00 & 17.00 & 18.00 \\
\hline & & $b$ & 14.50 & 15.00 & 29.00 & 29.00 \\
\hline & & $\mathrm{C}$ & 15.00 & 15.00 & 27.00 & 32.00 \\
\hline & \multirow{3}{*}{2016} & $a$ & 7.75 & 4.75 & 17.50 & 28.75 \\
\hline & & $b$ & 6.50 & 6.25 & 25.00 & 27.50 \\
\hline & & $\mathrm{C}$ & 6.50 & 3.75 & 18.05 & 29.75 \\
\hline \multirow{9}{*}{$\mathrm{N}_{\text {in }}$} & \multirow{3}{*}{2014} & $a$ & 57.23 & 48.45 & 28.40 & 18.35 \\
\hline & & $\mathrm{b}$ & 132.65 & 114.25 & 81.70 & 52.10 \\
\hline & & $\mathrm{c}$ & 95.45 & 89.85 & 78.00 & 72.40 \\
\hline & \multirow{3}{*}{2015} & $a$ & 45.70 & 44.20 & 47.10 & 48.00 \\
\hline & & $b$ & 108.80 & 105.40 & 106.20 & 79.50 \\
\hline & & c & 115.00 & 111.60 & 106.10 & 87.50 \\
\hline & \multirow{3}{*}{2016} & $a$ & 48.75 & 44.25 & 36.60 & 46.25 \\
\hline & & $\mathrm{b}$ & 135.10 & 123.75 & 86.75 & 68.00 \\
\hline & & c & 156.50 & 123.95 & 116.45 & 98.35 \\
\hline
\end{tabular}

Table 5. Dependence of yield parameters of radish roots on the contents of selected nitrogen forms in the soil substrate during the radish growth season expressed by the correlation coefficient ( $\mathrm{r}$ )

\begin{tabular}{|c|c|c|c|c|}
\hline \multirow{2}{*}{$\begin{array}{c}\text { Soil layer } \\
(\mathrm{m})\end{array}$} & \multicolumn{3}{|c|}{ Parameter } \\
\cline { 2 - 5 } & \multirow{2}{*}{ Dependent } & $\mathrm{N}_{\text {in }}$ & $\mathrm{N}^{+N_{3}}$ & $\mathrm{~N}_{3}^{-} \mathrm{NH}_{4}^{+}$ \\
\cline { 2 - 5 } & Yield & $0.648^{++}$ & $0.618^{++}$ & -0.051 \\
\hline \multirow{3}{*}{$0.0-0.1$} & $\mathrm{NaNO}_{3}$ & $0.595^{++}$ & $0.540^{++}$ & 0.097 \\
\cline { 2 - 5 } & Vitamin C & $-0.527^{++}$ & $-0.453^{++}$ & -0.233 \\
\cline { 2 - 5 } & Yield & $0.595^{++}$ & $0.564^{++}$ & 0.041 \\
\cline { 2 - 5 } $0.1-0.2$ & $\mathrm{NaNO}_{3}$ & $0.652^{++}$ & $0.575^{++}$ & 0.238 \\
\cline { 2 - 5 } & Vitamin C & $-0.641^{++}$ & $-0.527^{++}$ & $-0.410^{+}$ \\
\hline
\end{tabular}

Statistically significant at: ${ }^{+}-\mathrm{P}<0.05,{ }^{++}-\mathrm{P}<0.01 ; \mathrm{n}=36$.

of soluble sugars, of phenolic compounds, of carotenoids). Chessin and Hicks (1987) found out that along with the rising dose of $\mathrm{N}$ fertilizers, the content of nitrogen in carrot was increased linearly, but the content of nitrates was not influenced. Kováčik and Ryant (2019) state that in $85 \%$ of cases, nitrogen fertilization increases yields and deteriorates the quality of cultivated plants.

The detected in the experiment and statistically expressed dependences of the quantitative and qualitative parameters of radish root yield on $\mathrm{N}_{\text {in }}$ in substrate (Table 5) were unequally determined by nitrate and ammonium nitrogen. 
The dependence of three monitored yield parameters on the contents of nitrate nitrogen $(\mathrm{N}-$ $\mathrm{NO}_{3}^{-}$) observed in both soil layers was comparable with the dependence of the yield parameters on the contents of inorganic nitrogen. There was a positive correlation dependence between the root weight (yields) and $\mathrm{N}_{-} \mathrm{NO}_{3}{ }^{-}$contents in the substrate. The negative dependence was recorded between content of vitamin $\mathrm{C}$ in roots and content of $\mathrm{N}^{-\mathrm{NO}_{3}}{ }_{3}^{-}$in the substrate, on the other hand the positive dependence was between the nitrates contents in roots and the $\mathrm{N}^{-\mathrm{NO}_{3}}{ }^{-}$contents in the substrate. It is obvious that along with the rise of nitrate nitrogen content in the substrate there is the high probability that the radish root yield will be increased and the quality will fall, i.e. the content of vitamin $\mathrm{C}$ will be decreased and nitrates content will rise. These facts correspond with the statement of Lominadze and Nakashidze (2016) who claim that the accumulation of nitrates in plants is greatly influenced by the excess amount of its content in the soil. On the contrary, the different results were presented by Smoleń and Sady (2009b), who recorded in carrot roots $23 \%$ less nitrates after the nitrogen application in the form of nitrate $\left[\mathrm{Ca}\left(\mathrm{NO}_{3}\right)_{2}\right]$ than after the application of ammonium form $\left[\left(\mathrm{NH}_{4}\right)_{2} \mathrm{SO}_{4}\right]$.

The dependence of yield parameters on the $\mathrm{N}-\mathrm{NH}_{4}^{+}$contents was statistically insignificant, apart from one exception. The significant, negative dependence was recorded between the content of vitamin $\mathrm{C}$ and content of $\mathrm{N}^{-\mathrm{NH}_{4}}{ }^{+}$occurring in the soil layer $0.1-0.2 \mathrm{~m}$. This information emphasizes that in radish cultivation the formation of phytomass is determined more importantly by nitrate nitrogen than ammonium nitrogen. This fact corresponds with the data of Cox and Reisenauer (1973) who state that in order to achieve the maximal yields it is necessary to supply the plants with both forms of inorganic nitrogen.

The correlation dependence of the yield parameters of radish roots on the contents of selected forms of nitrogen in the substrate in the particular periods of growing season is expressed in the Table 6. These data show that the dependence of the root yield on the contents of nitrate

Table 6. Dependence of yield parameters of radish roots on the contents of selected nitrogen forms in the soil substrate in the different periods of the radish growth season expressed by the correlation coefficient (r)

\begin{tabular}{|c|c|c|c|c|c|}
\hline \multirow{2}{*}{$\begin{array}{l}\text { Soil layer } \\
\qquad(\mathrm{m})\end{array}$} & \multirow{2}{*}{ Form of $\mathrm{N}$} & \multirow{2}{*}{$\begin{array}{c}\text { Number of days after } \\
\text { sowing }\end{array}$} & Weight & $\mathrm{NaNO}_{3}$ & Vitamin C \\
\hline & & & \multicolumn{3}{|c|}{$r$} \\
\hline \multirow{12}{*}{$0.0-0.1$} & \multirow{4}{*}{$\mathrm{N}-\mathrm{NH}_{4}{ }^{+}$} & 22 & -0.471 & -0.053 & -0.250 \\
\hline & & 32 & -0.436 & -0.067 & -0.345 \\
\hline & & 42 & 0.272 & 0.374 & -0.555 \\
\hline & & 52 & 0.280 & 0.614 & $-0.783^{+}$ \\
\hline & \multirow{4}{*}{$\mathrm{N}-\mathrm{NO}_{3}^{-}$} & 22 & $0.852^{++}$ & 0.603 & -0.468 \\
\hline & & 32 & $0.798^{++}$ & 0.622 & -0.454 \\
\hline & & 42 & $0.701^{+}$ & $0.710^{+}$ & $-0.675^{+}$ \\
\hline & & 52 & 0.584 & $0.822^{+}$ & $-0.798^{++}$ \\
\hline & \multirow{4}{*}{$\mathrm{N}_{\text {in }}$} & 22 & $0.836^{++}$ & 0.612 & -0.495 \\
\hline & & 32 & $0.763^{+}$ & 0.622 & -0.494 \\
\hline & & 42 & $0.693^{+}$ & $0.691^{+}$ & $-0.676^{+}$ \\
\hline & & 52 & 0.551 & $0.807^{++}$ & $-0.812^{++}$ \\
\hline \multirow{12}{*}{$0.1-0.2$} & \multirow{4}{*}{$\mathrm{N}-\mathrm{NH}_{4}{ }^{+}$} & 22 & -0.541 & -0.203 & -0.236 \\
\hline & & 32 & -0.535 & -0.175 & -0.192 \\
\hline & & 42 & 0.218 & 0.546 & $-0.777^{+}$ \\
\hline & & 52 & 0.464 & $0.668^{+}$ & $-0.805^{++}$ \\
\hline & \multirow{4}{*}{$\mathrm{N}-\mathrm{NO}_{3}^{-}$} & 22 & $0.823^{++}$ & 0.650 & -0.531 \\
\hline & & 32 & $0.786^{+}$ & 0.659 & -0.577 \\
\hline & & 42 & 0.576 & $0.734^{+}$ & $-0.764^{+}$ \\
\hline & & 52 & 0.380 & $0.816^{++}$ & $-0.799^{++}$ \\
\hline & \multirow{4}{*}{$\mathrm{N}_{\text {in }}$} & 22 & $0.795+$ & 0.646 & -0.558 \\
\hline & & 32 & 0.722 & 0.640 & -0.604 \\
\hline & & 42 & 0.557 & $0.767^{+}$ & $-0.842^{++}$ \\
\hline & & 52 & 0.470 & $0.896^{++}$ & $-0.929^{++}$ \\
\hline
\end{tabular}

Statistically significant at: ${ }^{+}-\mathrm{P}<0.05,{ }^{++}-\mathrm{P}<0.01 ; \mathrm{n}=9$. 
nitrogen in soil was decreasing gradually in the course of radish growing season and the dependence of nitrates contents and vitamin $\mathrm{C}$ on the contents of $\mathrm{N}^{-\mathrm{NO}_{3}}{ }^{-}$in the substrate was increased over the time during the growing season. The nitrate nitrogen content in the both substrate layers had the positive impact on the yield quantity in the initial periods of the radish growing season. In the second half of the growth season it determined mainly the qualitative parameters, in particular negatively. On 42nd and 52nd day after sowing the negative correlation coefficients were recorded between the contents of vitamin $\mathrm{C}$ and the contents $\mathrm{N}_{-} \mathrm{NO}_{3}{ }^{-}$in substrate, and at the same time the positive correlation coefficients were detected between nitrates $\left(\mathrm{NaNO}_{3}\right)$ in roots and nitrate nitrogen $\left(\mathrm{N}^{-\mathrm{NO}_{3}}{ }^{-}\right)$in substrate.

The dependence of root yield on the content of ammonium nitrogen in both layers of substrate was insignificant during the whole monitored period of radish growth season. It was only negative trend in the initial period, which is related to a higher sensitivity of younger plants to the presence of ammonium nitrogen in soil. This fact also affirms the information that the increase of content of ammonium nitrogen in soil leads to the decrease of the phytomass production by the cultivated crops (Cox \& Reisenauer, 1973), or that ammonia and ammonium nitrogen is toxic for all living organisms, apart from low concentrations (Marschner, 2005), therefore young organisms react so sensitively (Kováćik \& Ryant, 2019).

The dependence of the nitrates contents in radish roots on the contents of ammonium nitrogen found in the substrate in the layer $0.0-0.1 \mathrm{~m}$ was also insignificant during the monitored period. It was only negative trend in the initial period and positive in the second half of the growing season. A similar tendency was also recorded in the second, deeper layer $(0.1-0.2 \mathrm{~m})$, whereby the correlation coefficient was statistically significant only in the last sampling.

The lack of the significant dependence of nitrates content in radish roots on the contents of ammonium nitrogen in the substrate does not mean that the accumulation of nitrates in their tissue can be avoided by the fertilization of vegetables by ammonium nitrogen. The reason is the fact that after the application of ammonium fertilizers into soil in many cases the supplied ammonium form $\mathrm{N}$ is being transformed into the nitrate form in the course of several days, at most weeks in the process of nitrification. The increased quantity $\mathrm{N}^{-\mathrm{NH}_{4}}{ }^{+}$in soil causes consequently the increased $\mathrm{N}^{+} \mathrm{NO}_{3}{ }^{-}$content in soil and then in plants (Kováčik and Ryant 2019).

Elwan and El-Hamed (2011) recorded that the application $\mathrm{N}$ fertilizer, containing nitrate nitrogen, decreased the content of vitamin $\mathrm{C}$ in comparison with other $\mathrm{N}$ fertilizers (that do not contain nitrate nitrogen) and did not have impact on the content of nitrates in broccoli.

The negative trend of dependence was registered between content of ammonium nitrogen in the substrate and vitamin $\mathrm{C}$ content in roots during the whole period of the study. The value of negative trend was increasing with the following days of the growth season and achieved the statistically significant value at the last sampling date (52nd day after sowing).

The requirements of plants and animals on nutrition are being changed during their life cycle. Therefore, the scientific teams evaluate constantly the impact of the various nutrients, nutritional substances in time on the quantity and quality of the cultivated crops and bred animals in order to grow crops and breed animals as effectively as possible. The plant nutrition in the improper time does not lead to the yield increase, on the contrary it can result in the yield decrease and deterioration of quality of the cultivated products. The data in the Table 6 indicate that the dependence of yield quantity on the content of inorganic nitrogen in the growing medium was higher at the beginning of the growing season. The yield dependence on the content $\mathrm{N}_{\text {in }}$ was decreased gradually along with the following days, which was valid for both layers of the substrate. On the contrary, the dependence of the qualitative yield parameters on the contents of $\mathrm{N}_{\text {in }}$ in the substrate was increased with the rising days. The recorded negative dependence between the content of vitamin $\mathrm{C}$ in roots and inorganic nitrogen content in soil (mainly in the second half of radish growth season) explains why farmers are founding out smaller content of vitamin $\mathrm{C}$ very often in the case of the crop cultivation in the organic agricultural system (fertilization only by organic fertilizers $=$ the gradual release of inorganic nitrogen) than in the crops grown conventionally, in which predominantly mineral or chemical fertilizers are applied (Ponder \& Halman, 2020). The reason of the recorded negative trend of dependence between the content of inorganic nitrogen in soil and content of vitamin C in plants is the fact that along with the increased 
content $\mathrm{N}_{\text {in }}$ in soil, its content in plants is also being increased, which results in the oxidative stress, i.e. the increased production of the oxygen radicals. The oxygen radicals are very effectively (intensively) "absorbed" by the antioxidant system of plants. The vitamin $\mathrm{C}$ also participates in its formation. This leads to the phenomenon that along with the increasing content of $\mathrm{N}_{\text {in }}$ in soil the content of the oxygen radicals is being increased and the content of the vitamin $\mathrm{C}$ is being decreased (Melino et al., 2009).

From the acquired data it is clear that in order to achieve high yields, it is important to ensure sufficient available nitrogen in the soil in the initial period of vegetation. Vice-versa, the increased quantity of inorganic nitrogen at the end of the growing season influences the qualitative parameters of vegetables, i.e. mostly negatively. The detected facts correspond fully with the information presented above, where we claim that the nitrogen taken by plants from the upper layers of soil (at the beginning of the growth season) determines mainly the yield quantity and the nitrogen taken from the deeper soil layers (in later periods of the growing season) determines mostly the yield quality. In this experiment the nitrogen taken in the second half of the growing season increased the content of nitrates and decreased the content of vitamin $\mathrm{C}$ in roots (Table 6). In the experiments of Ozer et al. (2004) and Kováčik et al. (2006) the nitrogen taken in the second half of the growing season increased the content of proteins and decreased the content of starch and fat in the seeds of field crops.

The neglect of the fact that the rational plant nutrition must take into consideration the contents of nutrients in soil and the processes of changes of their forms causes that many authors do not record the change of the yield parameters of plants after the application of the available nutrients into soil. Despite of this fact it is still valid that nitrogen is the most important nutrient having impact on the formation of phytomass in the crop cultivation (Kováčik \& Jančovič, 2001; Mandić et al., 2015).

\section{CONCLUSIONS}

The dependence of the radish yield parameters on the content of ammonium and nitrate nitrogen in soil was not equal. A higher dependence was registered between the radish yield parameters and the ${\mathrm{N}-\mathrm{NO}_{3}}_{3}$ - contents in soil substrate than the dependence between the yield parameters and $\mathrm{N}-\mathrm{NH}_{4}{ }^{+}$contents.

The dependence between the $\mathrm{N}-\mathrm{NH}_{4}{ }^{+}$contents and root yield was insignificant, however, it was negative trend in the first half of the growth season. The negative significant dependence was recorded between the contents of $\mathrm{N}-\mathrm{NH}_{4}{ }^{+}$and contents of vitamin $\mathrm{C}$ at the end of the growth season.

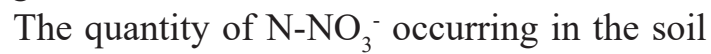
substrate in the initial period of the growing season had impact mostly on the yield quantity. The quantity of $\mathrm{N}_{-} \mathrm{NO}_{3}-$ present in the soil substrate in the second half of the growing season influenced mainly the content of vitamin $\mathrm{C}$ and content of nitrates in roots. It decreased the content of vitamin $\mathrm{C}$ and increased the content of nitrates.

The amount of the radish root yield depended mainly on the $\mathrm{N}_{\text {in }}$ contents occurring (detected) in the soil substrate at the beginning of the growth season. On the contrary, the content of nitrates and vitamin $\mathrm{C}$ (yield quality) depended predominantly on the contents $\mathrm{N}_{\text {in }}$ present in the soil substrate in the second half of the radish growth season. Along with the increasing $\mathrm{N}_{\text {in }}$ content the root yield was increased and also the content of nitrates in them, and the content of vitamin $\mathrm{C}$ was decreased.

The inorganic nitrogen, which will be taken by the radish plants from the upper soil layers (at the beginning of the growth season), will determine mainly the quantity of root yield. The nitrogen, which will be taken from the deeper soil layers (in the later period of the growth season), will determine mostly the qualitative yield parameters (content of vitamin $\mathrm{C}$ and nitrates).

\section{Acknowledgments}

This article was created on the basis of the solution of project VEGA No. 1/0378/20.

\section{REFERENCES}

1. Ball G.F.M. 1998. Vitamin C. In: Bioavailability and Analysis of Vitamins in Foods. Springer, Boston, MA. pp. 517-554. DOI: 10.1007/978-1-4899-3414-7_15

2. Bremner J.M. 1960. Determination of nitrogen in soil by the Kjeldahl method. Journal of Agricultural Science, 55, 1-23. 
3. Cox W.J., Reisenauer H.M. 1973. Growth and ion uptake by wheat supplied nitrogen as nitrate, or ammonium, or both. Plant and Soil, 38(2), 363-380. DOI: 10.10007/BF00779019

4. Chessin D.A., Hicks J.R. 1987. The effect of nitrogen fertilizer, herbicides and cultivar on nitrogen components of carrot roots. Scientia Horticulturae, 33(12), 67-73. DOI: 10.1016/0304-4238(87)90033-1

5. Dziadowiec H., Gonet S.S. 1999. Methodical guide-book for soil organic matter studies. Warszawa: Polish Society of Soil Science, pp. 65. ISSN 0860-1313; II/16

6. Elwan M.W.M., El-Hamed K.E.A. 2011. Influence of nitrogen form, growing season and sulphur fertilization on yield and the content of nitrate and vitamin C of broccoli. Scientia Horticulturae, 127(3), 181-187. DOI: 10.1016/j.scienta.2010.09.017

7. Fageria N.K., Baligar V.C. 2005. Enhancing nitrogen use efficiency in crop plants. Advances in Agronomy, 88, 97-185. DOI: 10.1016/ S0065-2113(05)88004-6

8. Hubáček J., Bernatzik K. 1979. Determination of nitrates in soil, plants and feeds Methodologies of implementing research results into practice. Bratislava: MP SSR. 52 pp.

9. Jin Z., Chen C., Chen X., Jiang F., Hopkins I., Zhang X., Han Z., Billy G., Benavides J. 2019. Soil acidity, available phosphorus content, and optimal biochar and nitrogen fertilizer application rates: A five-year field trial in upland red soil, China. Field Crops Research, 232, 77-87. DOI: 10.1016/j.fcr.2018.12.013

10. Kováčik P., Jančovič J. 2001. Deficiency symptoms of nitrogen, phosphorus, potassium and sulphur in radish plants. Acta fytotechnica et zootechnica, 4(2), 38-42.

11. Kováčik P., Jančovič J., Tomáš J. 2006. Nitrogen fertilization of spring barley at tillering stage. Agriculture (Pol'nohospodárstvo), 52(2), 77-86. https:/www.agriculture.sk/fileadmin/agriculture/ files/2006/Issue\%202/2-2006-77-86.pdf

12. Kováčik P. 2009. Výživa a systémy hnojení rostlin. České Budějovice: Kurent, s. r. o., 109 pp. ISBN 978-80-87111-16-1

13. Kováčik P., Žofajová A., Šimanský V., Halászová K. 2016. Spring barley yield parameters after lignite, sodium humate and nitrogen utilization. Agriculture (Pol'nohospodárstvo), 62(3), 80-89. DOI: 10.1515/ agri-2016-0009

14. Kováčik P., Ryant P. 2019. Agrochemistry (principles and practice). Nitra: SUA in Nitra, $358 \mathrm{pp}$. ISBN 978-80-55-2051-2

15. Lassaletta L., Billen G., Grizzetti B., Anglade J., Garnier J. 2014. 50. years trends in nitrogen use efficiency of world cropping systems: the relationship between yield and nitrogen input to cropland.
Environmental Research Letters, 9(10), 9 pp. article 105011. DOI: 10.1088/1748-9326/9/10/105011

16. Liu Q., Ma H., Lin X., Zhou X., Zhao Q. 2019. Effects of different types of fertilizers application on rice grain quality. Chilean Journal of Agricultural Research, 79(2), 202-209. DOI: 10.4067/ S0718-58392019000200202

17. Mandić V., Krnjaja V., Tomić Z., Bijelić Z., Simić A., Ruzić-Muslić D., Gogić M. 2015. Nitrogen fertilizer influence on wheat yield and use efficiency under different environmental conditions. Chilean Journal of Agricultural Research, 75(1), 92-97. DOI: $10.4067 / \mathrm{S} 0718-58392015000100013$

18. Lominadze S., Nakashidze N. 2016. The influence of nitrogen fertilizers on nitrate accumulation in leaves of orange Washington Navel. Annals of Agrarian Science, 14(3), 233-236. DOI: 10.1016/j. aasci.2016.07.008

19. Mehlich A. 1984. Mehlich 3 soil test extractant: A modification of Mehlich 2 extractant. Communication in Soil Science and Plant Analysis, 15(12), 1409-1416. DOI: 10.1080/00103628409367568

20. Marschner H. 2005. Mineral nutrition of higher plants. London: Elsevier Academic Press. 889 pp. ISBN 0-12-473543-6

21. Melino V.J., Soole K.L., Ford Ch.M. 2009. Ascorbate metabolism and the developmental demand for tartaric and oxalic acids in ripening grape berries. BMC Plant Biology, 9, 145, 14 pp. DOI: 10.1186/1471-2229-9-145

22. Mueller N.D., Gerber J.S., Johnston M., Ray D.K., Ramankutty N., Foley J.A. 2012. Closing yield gaps through nutrient and water management. Nature, 490, 254-257. DOI: 10.1038/nature 11420

23. Özer H., Polat T., Öztürk E. 2004. Response of irrigated sunflower (Helianthus annuus L.) hybrids to nitrogen fertilization: growth, yield and yield components. Plant, Soil and Environment, 50(5), 205-211.

24. Ponder A., Hallmann E. 2020. The nutritional value and vitamin $\mathrm{C}$ content of different raspberry cultivars from organic and conventional production. Journal of Food Composition and Analysis, 87, 103429. DOI: 10.1016/j.jfca.2020.103429

25. Prasad R., Shivay Y. S. 2016. Deep placement and foliar fertilization of nitrogen for increased use efficiency - An overview. Indian Journal of Agronomy, 61(4), 420-424.

26. Rodrigues M.Â., Coelho V., Arrobas M., Gouveia E., Raimundo S., Correia C.M., Bento A. 2019. The effect of nitrogen fertilization on the incidence of olive fruit fly, olive leaf spot and olive anthracnose in two olive cultivars grown in rainfed conditions. Scientia Horticulturae, 256, 108658. DOI: 10.1016/j. scienta.2019.108658 
27. Smoleń S., Sady W. 2009a. The effect of various nitrogen fertilization and foliar nutrition regimes on the concentrations of sugars, carotenoids and phenolic compounds in carrot (Daucus carota L.). Scientia Horticulturae, 120(3), 315-324. DOI: 10.1016/j. scienta.2008.11.029

28. Smoleń S., Sady W. 2009b. The effect of various nitrogen fertilization and foliar nutrition regimes on the concentrations of nitrates, ammonium ions, dry matter and N-total in carrot (Daucus carota L.) roots. Scientia Horticulturae, 119(3), 219-231. DOI: $10.1016 /$ j.scienta.2008.07.030

29. Šlosár M., Čekey N., Uher A., Balogh Z. 2009. The influence of nitrogen fertilization on the yield and nitrate cumulation in the broccoli. Acta Horticulturae et Regiotecturae, 12(1), 14-17.

30. Uher A., Mezeyová I., Hegedűsová A., Šlosár M. 2017. Impact of nutrition on the quality and quantity of cauliflower florets. Potravinarstvo Slovak Journal of Food Sciences, 11(1), 113-119. DOI: 10.5219/723

31. Zachar D. 2006. Human nutrition I. General part. Zvolen: TU vo Zvolene, pp. 265.

32. Zhang X., Davidson E., Mauzerall D., Searchinger T., Dumas P., Shen Y. 2015. Managing nitrogen for sustainable development. Nature, 528, 51-59. DOI: 10.1038 /nature 15743 